\title{
FORMULASI DAN EVALUASI FISIK SEDIAAN MASKER SHEET (SHEET MASK) KOMBINASI VCO (VIRGIN COCONUT OIL), ASAM ASKORBAT DAN $\alpha$-TOCOPHEROL
}

\author{
Anggun Hari Kusumawati ${ }^{1 *}$, Kesya Yonathan ${ }^{1}$, Dadan Ridwanuloh $^{1}$, Ike Widyaningrum ${ }^{2}$ \\ ${ }^{1}$ Prodi Farmasi, Fakultas Farmasi, Universitas Buana Perjuangan, Karawang. \\ ${ }^{2}$ Prodi Farmasi, Fakultas Kedokteran, Universitas Islam Malang, Malang. \\ *Penulis korespondensi: anggunhari@ubpkarawang.ac.id
}

\begin{abstract}
ABSTRAK
Kulit yang sehat dapat mencerminkan kesehatan seseorang. Menjadikan kulit sehat, bersih dan cerah merupakan idaman semua orang terutama pada wanita. Antioksidan melindungi tubuh dari kerusakan yang disebabkan oleh radikal bebas. Radikal bebas dapat menyebabkan kerusakan sel seperti mengalami kulit keriput, timbul flek hitam, dan wajah kusam. Virgin Coconut Oil mengandung asam lemak jenuh yaitu asam kaproat, asam kaprilat, asam kaprat, asam laurat $( \pm 53 \%)$, asam miristat dan tokoferol $(0,5 \mathrm{mg} / 100 \mathrm{~g})$, dan kombinasi asam askorbat dengan $\alpha$-tocopherol untuk menambah efektifitas whitening pada sheet mask. Penelitian ini bertujuan membuat sheet mask dengan sifat fisik yang baik, formulasi dibuat dengan konsentrasi zat aktif yang berbeda dan dilakukan uji sifat fisik meliputi uji organoleptik, uji homogenitas, uji $\mathrm{pH}$, uji viskositas, uji iritasi. Hasil uji organoleptik dan uji homogenitas masing-masing formulasi memiliki warna putih, bau khas sakura, memiliki tekstur semi cair dan uji homogenitas dapat dikatakan homogen, hasil uji viskositas (F1) $244,4 \pm 27,5$ cps (F2) 242,1 $\pm 12,8$ cps, (F3) 261,4 $\pm 29,6$ hasil uji pH (F1) 5,81 $\pm 0,047$ (F2) $5,39 \pm 0,049$ (F3) 5,28 $\pm 0,043$ masing-masing formulasi sudah optimal sesuai dengan kriteria yang ada, dan hasil uji iritasi dari 40 panelis tidak terjadi iritasi hal ini disebabkan karena $\mathrm{pH}$ sediaan masih dalam rentang $\mathrm{pH}$ kulit yaitu 4-6.
\end{abstract}

Kata kunci: Virgin Coconut Oil, Sheet mask, $\alpha$-tocopherol, Asam askorbat.

\section{FORMULATION AND PHYSICAL EVALUATION OF SHEET MASK COMBINATION OF VCO (VIRGIN COCONUT OIL), ASCORBATE $A C I D$ AND $\alpha$-TOCOPHEROL}

\begin{abstract}
Healthy skin can reflect one's health. Making healthy, clean and beautiful skin is everyone's dream of women. Antioxidants protect the body from damage caused by free radicals. Radicals can cause cell damage such as removing wrinkled skin, black flex arising, and dull face. Pure coconut oil contains saturated fatty acids namely caproat acid, caprylic acid, capric acid, lauric acid ( \pm 53\%), myristic acid and tocopherol (0.5 mg / 100g), and a combination of ascorbic acid with $\alpha$-tocopherol to increase the effectiveness of whitening on sheet masks. The aim of this research is made a mask sheet with good physical properties,
\end{abstract}


formulations were made using different active substances and physical tests were carried out on organoleptic tests, homogeneity tests, pH tests, viscosity tests, irritation tests. Organoleptic test results and homogeneity test of each formulation has a white color, characteristic odor of sakura, has a semi-liquid texture and homogeneity test can provide homogeneous, viscosity test results (F1) $244.4 \pm 27.5$ cps (F2) $242.1 \pm 12.8 \mathrm{cps}$, (F3) 261.4 $\pm 29.6 \mathrm{pH}$ (F1) test results $5.81 \pm 0.047$ (F2) $5.39 \pm 0.049$ (F3) $5.28 \pm 0.043$, each formulation is optimal in accordance with existing criteria, and the results of irritation test from 40 panels does not occur irritation because the $\mathrm{pH}$ of samples are still in the range of skin $\mathrm{pH}$.

keywords: Virgin Coconut Oil, Sheet Mask, $\alpha$-tocopherol, Ascorbic acid.

\section{PENDAHULUAN}

Kulit yang sehat dapat mencerminkan kesehatan seseorang. Menjadikan kulit sehat, bersih dan cerah merupakan idaman semua orang terutama pada wanita. Antioksidan melindungi tubuh dari kerusakan yang disebabkan oleh radikal bebas, radikal bebas dibentuk apabila oksigen tidak berpasangan satu atau lebih yang dapat menyebabkan kerusakan sel seperti mengalami kulit keriput, timbul flex hitam, wajah kusam. Vitamin C dan vitamin E merupakan antioksidan apabila dikombinasi maka dapat meningkatkan efektifitas antioksidan pada kulit dan dapat mengurangi proses pembentukan pigmen kulit dengan cara menghambat enzim teroksinase, enzim teroksinase ini adalah enzim pembentuk melanin dan mengubah warna kulit menjadi kehitaman atau warna coklat pada kulit (Villarino et al., 2007).

Salah satu keunggulan minyak kelapa adalah terletak pada 90\% kandungan asam lemak jenuhnya yaitu asam kaprilat, asam kaprat, asam laurat, asam miristat, dan tokoferol. Kandungan asam laurat $( \pm 53 \%)$ dan tokoferol $(0,5 \mathrm{mg} / 100 \mathrm{~g})$ dapat bersifat sebagai antioksidan (Villarino dan Lizada, 2007). Salah satu sediaan kosmetik wajah yang berguna sebagai perawatan kulit adalah masker wajah. Berbagai perusahaan kosmetik besar saat ini banyak mengeluarkan produk yang berbahan alami atau back to nature. Salah satu masker yang sedang trend dan popular di asia saat ini adalah masker sheet mask, memiliki pengemasan yang efektif dan higienis (hanya satu kali pemakaian) dan tidak perlu dibersihkan setelah pemakaian (Reveny et al., 2017) selain itu mencegah penguapan fase air yang cepat dan memperpanjang jangka waktu bahan yang dibutuhkan untuk menembus jauh ke dalam kulit (Nilforoushzaadeh et al., 2018).

Berdasarkan latar belakang di atas, maka penulis ingin melakukan penelitian tentang evaluasi fisik sediaan sheet mask yang berbahan dasar VCO dengan kombinasi $\alpha$-tocopherol dengan asam askorbat. 


\section{BAHAN DAN METODE}

Alat

Alat yang digunakan adalah gelas ukur, gelas beaker, batang pengaduk, spatula, pipet tetes, cawan petri, kaca arloji, neraca analitik (Adam PW254) viskometer (Lamy Rheologi First Touch 15.04T. F016), pH meter (NeoMet pH-240L GJ-7726), magnetic mixer (IKA CMAG HS 7), homogenizer (WiseTis HG-15D).

\section{Bahan}

$\mathrm{VCO}, \alpha$-tocopherol, asam askorbat, HPMC, propilenglikol, gliserin, tween 80, span 80, natrium benzoate, sakura oil, aquadest, lembaran kertas sheet mask.

\section{Prosedur Penelitian}

Tabel 1. Formula sediaan Sheet

\begin{tabular}{llccc}
\hline \multirow{2}{*}{ No. } & \multicolumn{1}{c}{ Bahan } & \multicolumn{3}{c}{ Jumlah $(\mathrm{g})$} \\
\cline { 3 - 5 } 1 & VCO & F1 & F2 & F3 \\
2 & HPMC & 0.25 & 6.25 & 6.25 \\
3 & A-tocopherol & 0,00497 & 0,3 & 0,3 \\
4 & Asam Askorbat & 0.01 & 0,03 & 0,250 \\
5 & Natrium Benzoat & 0.1 & 0.1 & 0.1 \\
6 & Propilen Glikol & 15.59 & 15.59 & 15.59 \\
7 & Gliserin & 18.93 & 18.93 & 18.93 \\
8 & Tween 80 & 2.21 & 2.21 & 2.21 \\
9 & Span 80 & 4.70 & 4.70 & 4.70 \\
10 & Oleum Sakura & 3 Tetes & 3 Tetes & 3 Tetes \\
11 & Aquadest & 51.89 & 51.87 & 51.34 \\
\hline
\end{tabular}

\section{Preparasi Sediaan}

Timbang semua bahan, hidupkan alat magnetic mixer, masukan magnet ke dalam Beaker Glass selanjutnya masukan asam askorbat, natrium benzoate dan aquadest kedalam Beaker Glass hingga homogen tambahkan HPMC kedalam Beaker Glass hingga membentuk gel, masukan wadah A (propilen glikol, gliserin) hingga homogen. Masukan wadah B (VCO, $\alpha$-tocopherol, asam askorbat, fragrance, tween 80, span 80) hingga homogen menggunakan magnetic mixer, setelah homogen gunakan homogenizer agar essence sheet mask dapat lebih homogen. 


\section{Evaluasi Sediaan}

1. Uji Organoleptik

Pemeriksaan organoleptik dilakukan dengan melihat secara visual dan mengamati perubahan-perubahan yang terjadi pada sediaan, yakni meliputi penampilan, warna dan bau.

2. $\mathrm{Uji} \mathrm{pH}$

Pengukuran $\mathrm{pH}$ dilakukan dengan menggunakan $\mathrm{pH}$ meter, masing-masing formula harus memenuhi rentang $\mathrm{pH}$ dengan kisaran sesuai $\mathrm{pH}$ kulit yaitu 4,5-6,5.

3. Uji Homogenitas

Pemeriksaan homogenitas dilakukan dengan cara meletakan sediaan diantara dua kaca objek dan diamati ada atau tidaknya partikel kasar yang terdapat dalam sediaan.

4. Uji Viskositas

Sebanyak 100 gram sediaan dimasukan ke dalam gelas beaker $100 \mathrm{ml}$ kemudian diukur viskositasnya dengan viscometer, kemudian diatur spindel dan kecepatan yang digunakan.

5. Uji Iritasi

Uji tempel atau uji iritasi adalah kepekaan kulit yang dilakukan dengan cara mengoleskan sediaan uji pada kulit normal panel manusia dengan maksud mengetahui apakah sediaan dapat menimbulkan iritasi pada kulit atau tidak, tanda-tanda reaksi kulit yang ditimbulkan yaitu hipermia, eritema, edema atau vesikula kulit. Reaksi kulit yang demikian bersifat lokal pada daerah yang dioleskan saja.

\section{HASIL DAN PEMBAHASAN}

\section{Uji Sifat Fisik Sheet Mask}

Tabel 2. Hasil evaluasi sediaan Sheet Mask

\begin{tabular}{llllll}
\hline Evaluasi & Syarat & F0 & F1 & F2 & F3 \\
\hline Uji viskositas (cps) & $137-275$ & 155,0 & 244,4 & 242,1 & 261,4 \\
Uji pH & $4,5-6,5$ & 6.02 & 5,81 & 5,39 & 5,28 \\
Uji Homogenitas & Homogen & Homogen & Homogen & Homogen & Homogen \\
\hline
\end{tabular}




\section{Uji Organoleptik}

Uji Organoleptik bertujuan untuk mengetahui sifat fisik sediaan secara visual dengan melihat wujud dari warna, bau, tekstur sediaan sheet mask yang telah dibuat. Pada pengujian organoleptik semua formulasi menghasilkan sediaan sheet mask yang baik. Warna masing masing sediaan berwarna putih, memiliki tekstur semi cair dan memiliki bau khas sakura.

\section{Uji Homogenitas}

Uji Homogenitas bertujuan untuk mengetahui apakah terdapat ketidakcampuran atau partikel-partikel kasar terhadap sediaan yang telah dibuat dengan cara meletakan sediaan diantara dua kaca objek lalu diamati. Dari Formulasi sheet mask tidak terlihat partikelpartikel kasar dan dapat dikatakan homogen.

\section{Uji Viskositas}

Uji Viskositas bertujuan untuk mengetahui seberapa tinggi tingkat kekentalan dari suatu cairan. Dilihat pada F0 hasil viskositas cukup rendah yakni 155,0 $\pm 2.02 \mathrm{cps}$ hal tersebut dikarenakan tidak menggunakan zat aktif menurut Novilla tahun 2017 VCO memiliki kandungan asam stearat sebanyak 5,68\%. Menurut Reveny dkk (2016) standar viskositas sheet mask antara $137-275$ cps pada F1 dengan nilai viskositas $244,4 \pm 27,5$ cps F2 dengan viskositas 242,1 $\pm 12,8$ cps, F3 dengan viskositas 261,4 \pm 29,6 cps maka Sheet mask dinyatakan sudah termasuk dalam kriteria.

\section{Uji pH}

Uji $\mathrm{pH}$ bertujuan untuk mengetahui tingkat keasaman yakni dengan $\mathrm{pH}$ antara $<7$ atau tingkat kebasaan yakni dengan $\mathrm{pH}$ antara $7>$ suatu sediaan, agar tidak mengiritasi kulit (asam) maupun membuat kulit menjadi kering (basa). Dari hasil uji $\mathrm{pH}$ dapat dilihat pada F0 memiliki pH 6.02 \pm 0,037 hal ini dikarenakan pada F0 (Blanko) tidak diberikan zat aktif baik itu VCO, $\alpha$-tocopherol maupun Asam Askorbat sehingga memiliki pH tidak begitu asam. pada F1 memiliki pH 5,81 \pm 0,047 pada F2 memiliki pH 5,39 $\pm 0,049$ pada F3 pH 5,28 \pm 0,043 hal ini terjadi karena adanya tingkat konsentrasi Vitamin C yang memiliki sifat asam sehingga dapat menurunkan $\mathrm{pH}$ namun dari ke tiga formulasi tersebut sudah termasuk kedalam kriteria pH kulit umumnya sekitar 4,5-6,5 (Tranggono, 2007). 
Uji Iritasi

Uji iritasi bertujuan untuk melihat keamanan dari sediaan terhadap sukarelawan dengan cara ditempelkan pada bawah telinga selama 10menit untuk melihat apakah menimbulkan kemerahan,gatal, pembengkakan, tidak terjadi apa-apa atau lainnya. tingkat iritasi berjumlah 0 dapat dikatakan tidak iritasi (ABICH, 2014).

Dari 40 panelis yang sudah diuji iritasi berkata tidak terjadi apa-apa hal ini disebabkan dari nilai $\mathrm{pH}$ sediaan sheet mask yang relatif normal dengan $\mathrm{pH} 5$ sedangkan $\mathrm{pH}$ kulit umumnya sekitar 4,5-6,5 (Tranggono, 2007).

\section{KESIMPULAN}

Berdasarkan hasil pengujian sifat fisik yang terdiri dari uji organoleptik, uji homogenitas, uji $\mathrm{pH}$, uji viskositas masing-masing sediaan memiliki sifat fisik yang baik. Hasil uji organoleptik dan uji homogenitas masing-masing formulasi memiliki warna putih, bau khas sakura, memiliki tekstur semi cair dan uji homogenitas dapat dikatakan homogen, hasil uji viskositas (F1) 244,4 \pm 27,5 cps (F2) 242,1 $\pm 12,8 \mathrm{cps,} \mathrm{(F3)} \mathrm{261,4} \pm$ 29,6 hasil uji pH (F1) 5,81 \pm 0,047 (F2) 5,39 \pm 0,049 (F3) 5,28 \pm 0,043 masing-masing formulasi sudah optimal sesuai dengan kriteria yang ada. Dari 40 panelis yang sudah diuji iritasi berkata tidak terjadi iritasi apa-apa karena $\mathrm{pH}$ sediaan sheet mask yang relatif normal yaitu $\mathrm{pH} 5$ yang masuk ke dalam range pH kulit sekitar 4-6.

\section{UCAPAN TERIMAKASIH}

1. LPPM Universitas Buana Perjuangan Karawang yang telah memberikan dana stimulus penelitian.

2. Para Staff Laboratorium Farmasi Universitas Buana Perjuangan Karawang.

\section{DAFTAR PUSTAKA}

ABICH. Assessment of Dermal Compatibility (Irritant Potential). Italia. 2014.

Levine, M., Dhariwal, K.R., Welch, R.W., Wang, Y., Park, J.B. Determination of Optial Vitamin C Requirements in Humans. The American Journal of Clinical Nutrition. Am J Clin Nutr. 1995; 62(6):1347S-1356S.

Novilla, A., Nursidika, P., Resmelia, M. Potensi Asam Lemak Pada Minyak Kelapa Murni DalamMenghambat Candida AlbicansSecara In Vitro. Maj. Kedokt. Bdg, 2016; 48, 200-204. 
Nilforouzhzade, M.A., Amirkhani M.A., Zarrintaj, P., Moghaddam, A.S., Mehrabi, T., Alavi, S., Sisakht, M.M. Skin Care Rejuvenation by Cosmeceutical Facial Mask. Journal of Cosmetic Dermatology. 2018; 17(5). 693-702.

Reveny, J., Surjanto, Tanuwijaya, J., Lois K. Formulation of Aloe Juice (Aloe vera (L) Burm.F.) Sheet mask As Anti-Aging. International Jurnal of Pharm Tech Research, 2016.

Reveny, J., Surjanto, Tanuwijaya, J., Lois K. Formulation and Evaluating Anti-Aging Effect of Vitamin E in Biocellulose Sheet Mask. Interational Jurnal Of Pharm Tech Research, 2016.

Tranggono, Retno I., Fatma L. Buku Pegangan Ilmu Kosmetik. Jakarta: PT Gramedia Pustaka Utama. 2007.

Villarino, B.J., Dy, L.M., Lizada, C.C., 2007, Descriptive Sensory Evaluation of Virgin Coconut Oil and Refined, Bleached and Deoderized Coconut Oil, LTW-Food Sci. Technol, 2007; 40, 193-199. 